\title{
花崗岩地域における地震時落石の発生場所・落下方向・到達距離の予測 \\ Prediction of location, falling direction and \\ falling distance of earthquake-induced rock falls in granite area
}

\author{
横山俊治 ${ }^{*)} \cdot$ 水口真一*) $・$ 藤田勝代 ${ }^{* *)} \cdot$ 嘉茂美佐子 ${ }^{* *)} \cdot$ 菊山浩喜 $\left.* * * *\right)$ \\ Shunji YOKOYAMA, Shinichi MIZUGUCHI, Masayo FUJITA, Misako KAMO and Hiroki KIKUYAMA
}

\begin{abstract}
This paper examined a prediction method of location, falling direction and falling distance of rock falls caused by horizontal earthquake motion in granite area. Many rock falls took place on mountain ridges and near convex break of slope where earthquake motion was probably amplified. Earthquake damages were bigger in ccomparatively fresh and fracture-poor granite than in strong-disintegrated or fracture-rich one. Then dominant movement types of earthquake-induced rock falls were of toppling and tumbling of large granite boulders on mountain ridges, jumping of large jointed blocks from fresh granite-outcropped scarps near convex break of slope and jumping of weak-disintegrated blocks from strong-disintegrated granite cliff near the top of road-cuts. The falling direction tends to orient perpendicular to the seismic faults. The distance of free falling from road-cuts tends to become equal about to height of falling position. On the basis of these features this paper has proposed a tool for selection of location of earthquake-induced rock falls in granite area.
\end{abstract}

Key words : granite, earthquake, rock fall, prediction

\section{和文要旨}

本論文では, 花崗岩地域において水平地震動によって引き起こされる落石の発生場所や，落下方向，落下距離を予测する方法を 考察した。多くの落石は，地震動がおそらく增幅したと思われる尾根や遷急線近傍で発生した。地震被害は風化した岩石や割れ目 の多い岩石よりも比較的新鮮で割れ目のそしい岩石で大きかった。それで地震時落石の卓越する運動タイプは，尾根上にあった花 南岩巨啋の転倒・転落と，遷急線近傍に位置する新鮮な岩石が露出している崖で発生する節理で囲まれた岩塊の横跳び，道路切土 法面の頂部付近で発生する強風化花崗岩中の弱風化岩塊の横跳びであった。落下方向は震源断層に直交する傾问がある。道路切土 法面から自由落下した落石の到達距離は落石発生場所の高さとほほ等しくなる倾向がある。これらの特徵に基づいて，花南岩地域 の地霞時落石発生場所の選定ツールを提案した。

キーワード: 花崗岩, 地震, 落石, 予測

\section{1. はじめに}

最近，西南日本内带で発生した地震，たとえば, 1995 年兵庫県南部地震や2000年鳥取県西部地震, 2001年芸予 地震では, 強震動領域に複数の地質体が分布しているに もかかわらず, 山地斜面における斜面変動は花崗岩地域 に集中した。たとえば, 兵庫県南部地震では, 空中写真 で判読された斜面崩壊だけでも700箅所を越えている゙が, 空中写真では判読の難しい小規模なものを含めると, 発 生筒所数はさらにその数倍になると思われる。そしてそ れらのほとんどが花崗岩地域で発生している。小規模な ものは径 $1 \mathrm{~m}$ 前後から $5 \mathrm{~m}$ 程度の単独岩塊の落石である。 発生数では落石が斜面崩壊をはるかに上まわっている。 しかもその斜面崩壊も, 現象は滑落というょりも崩落が ふさわしい形態を示している。すなわち, 兵庫県南部地 震では, 花崗岩地域において落石・崩落が多発したとい うことである。こういったことは鳥取県西部地震や芸予 地震でも認められる。

学知大学理学部自然環境科学科防災科学コース

Natural Hazard Prevention Science Course. Department of Natural Environment Science. Faculty of Science, Kochi Univ.

T 780-8520 高知県岁知市曙町 2-5-1

2-5-1 Akebono-cho, Kochi, 780-8520 Japan

**) 財深田地所研究所

Fukada Geological Institute

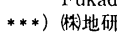

Chiken Co.. Ltd.

****) 川崎地椞(侏) 北目本支社

Kawasaki Geological Engineering Co. Ltd. Kita-Nihon Branch
落石は地震時でなくとも発生し，道路を走行中の車に 直撃して惨事になることもある。移動体の規模が小さい にもかかわらず，時に惨事を招くのが落石である。地震 時にはその落石が花崗岩地域において瞬時に多発するの で，その予測と対策が地震防災の重要な課題になってく るのである。

ところで，兵庫県南部地震で大きな被害が出た六甲山 地では, 豪雨時には過去に何度もマサ（強風化花崗岩） の表層崩壊一土石流が発生し，流出した土砂・流极が甚 大な被害をもたらしてきた。このように同質の地質体の， しかも近傍域で，豪雨時にも，地震時にも災害が多発す るといったことは，花崗岩以外ではあまり見られないこ とである。地形・地質条件の異なる豪雨時斜面変動と地 震時斜面変動が花崗岩地域において多発した要因は，花 崗岩の風化帯構造とそれを反映した特有の地形にあるも のと考えられる。

本論文では，はじめに兵庫県南部地震と鳥取県西部地 震，芸予地震を例に22334)，花崗岩地域で発生した地震時 落石・崩落の変動形態とそれを規制した花崗岩地域に特 有の地形条件と地質条件を明らかにする。つきにその結 果に基づいて, 地震時落石・崩落の発生場所や，落石の 落下方向, 落石の到達距離などの予測方法を検討する。 


\section{2. 地震時落石・崩落の変動形態}

図-1のタイプ 1 のイプ 6 は, 兵庫県南部地震によ る六甲花崗岩の斜面変動を変動形態に基づいて分類した ものである゙。 タイプ 1 , タイプ 2 , タイプ 3 は新鮮な 岩石の分布する地域で観察されたもので，タイプ $4 ，$ 夕 イプ 5 , タイプ 6 はマサの分布する地域で観察されたも のである。

図-1の夕イプ 7 は鳥取県西部地震と芸予地震で多発 した落石・崩落で, 兵庫県南部地震で記載された各夕イ プとは異なり, 弱風化岩とマサが混在する切土法面で観 察された。
タイプ 1 は尾根上に分布する花崗岩巨砂（径 $1 \mathrm{~m}$ 前後 から数m）の転倒・移動で，変動時に尾根からはずれる と落石になる。転倒はしばしば横跳びを伴い，落石を免 れた花崗岩巨砂は変動前の位置から離れたところに倒れ ている。このような現象は墓石や灯籠でもしばしば認め られ，慣性力によって地表地震動の水平加速度方位とは 反対側に横跳び・転倒したものと考えられる5)。移動は 重心の低い花崗岩巨礫でもみられる。ある事例では，花 崗岩巨礫の一方が持ち上がった後, 元に戻るときに持ち 上がった側とは反対側がすべりを起こして移動している。 タイプ 2 は新鮮な岩石の露出している崖 (露頭崖) か

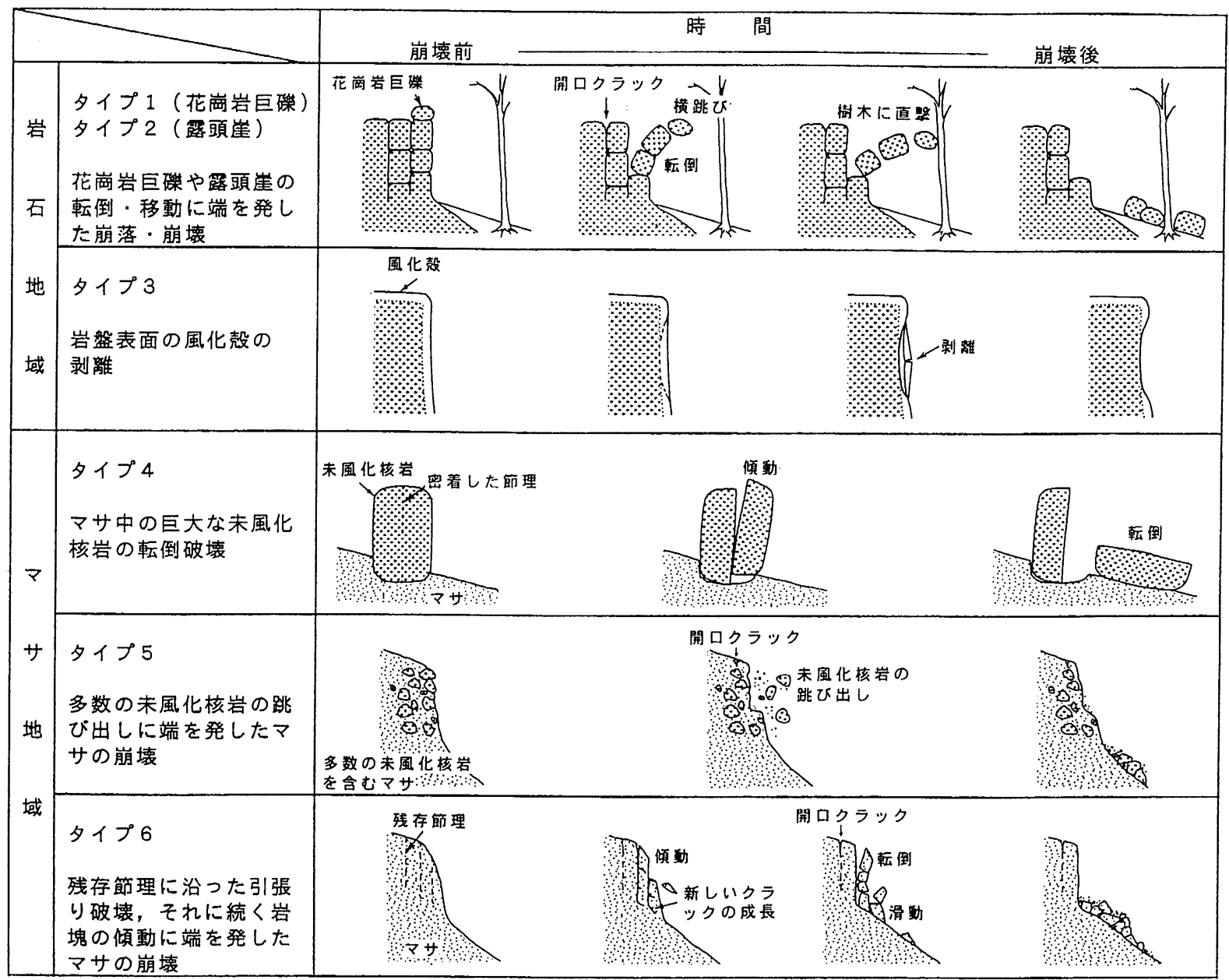

\section{タイプ7}

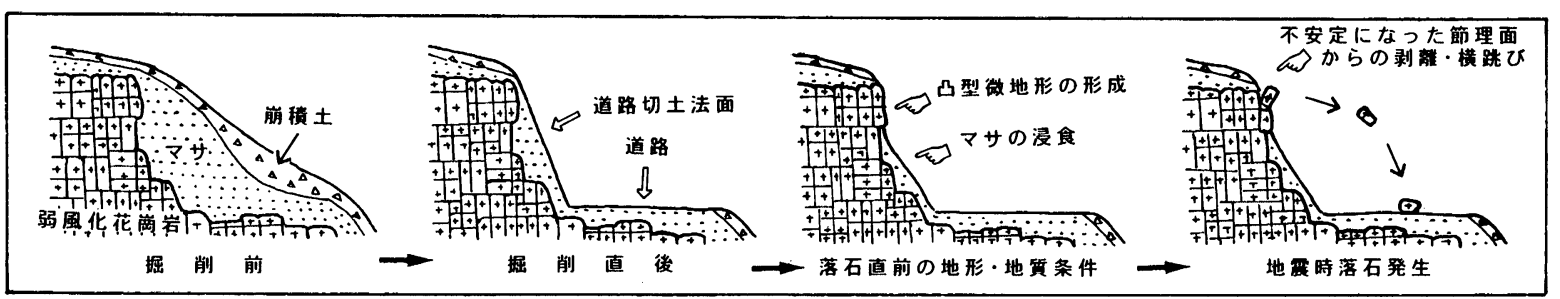

図-1 花崗岩地域の地震時斜面変動の分類

(タイプ1〜タイプ 6 （1995年兵庫県南部地震 $\left.{ }^{5}\right)$, タイプ 7 (2000年鳥取県西部地震 ${ }^{5}$ およよび2001年芸予地震 $\left.\left.{ }^{4}\right)\right)$

Fig. 1 Classification of earthquake-induced slope movements

(Movement type 1 to 6 (the 1995 Hyogo-Ken Nanbu Earthquake ${ }^{5)}$ ), and movement type 7 (the 2000 Tottori-ken Seibu Earthquake ${ }^{3)}$ and the Geiyo Earthquake $\left.{ }^{4}\right)$ ) 
ら方状節理に囲まれた岩塊が跳びだし，それが落石・崩 落になったものである。岩塊が跳びだす現象は地震時落 石・崩落の特徵であり, 露頭崖の正面に樹木が自生して いれば，跳びでた岩塊はしばしばその樹木に衝突してい る。露頭崖から離れた樹木の高い位置に付いた衝突の傷 は，落石が発生時に大きな初速度をもっていたことを示 す証拠となる。

タイプ 3 は花崗岩巨碟の表面の薄い風化殼がその内部 の新鮮な岩石との境界に沿って剥離したものである。剥 離面の面積は $10^{3} \sim 10^{5} \mathrm{~cm}^{2}$ 程度と小規模なものが普通で, それがとくに防災上問題になることはないが, 地震時斜 面変動としては特記すべきことである。タイプ 3 の剥離 は斜面の吹き付けコンクリートやビル外壁のタイル, 土 壁の漆喰などに見られる地震時の剥離 ${ }^{6}$ と類似した現象 である。地震動による剥離は, 振動エネルギーの減衰の 度合いが材料ごとに異なるために, 相接する材料間で応 答周期に違いが生じて発生したと考えられる。

マサ地域で観察された各夕イプも, 転倒や, 剥離を伴 う横跳びである。

タイプ 4 はマサ中の未風化核岩の転倒崩壊である。周 辺のマサが浸食で失われた未風化核岩が潜在節理に沿っ て二つに割れ，その一方が転倒した事例が芦屋のロック ガーデンで記載されている ${ }^{2}$ 。しかし, 多くの未風化核 岩は, しばしば高角度の潜在節理に沿って二つに割れて いるが，その周囲のほとんどを包んでいるマサが崩れな かったために, 転倒を免れている。このように通常は未 風化核岩の転倒は少なく，落石に移行することも少ない。 タイプ 5 はマサ中の風化を免れた角礫状岩塊の跳びだ しである。角礫状岩塊の跳びだしと同時にマサの部分が 崩れることもあるが，その場合も，マサが崩れた結果と して角砂状岩塊が落下したのではなかったために, はじ めに跳んだ角磁状岩塊は遠くに落下している。このよう なマサと角礫状岩塊とが混在した花崗岩は六甲断層系の 断層近傍に発達する。マサ化は小断層に沿って進行し, 角碟状の岩塊が残される。タイプ 5 の典型は, 灘区鶴甲 の六甲山地南麓を走る諏訪山断層の断層崖で発生した。 この例では, 崩壊深は浅く, 崩壊は角碟状岩塊が地表に 露出していた部分で発生し, マサのみが露出していた部 分は崩壊せずに残った。新鮮な岩塊だけが跳びだすとい う現象は段丘層や空石積み擁壁でも起こっていて, そこ でも, 段丘礫や空石積みの石といった新鮮な岩塊は跳び だすが, 岩塊の周囲や背後の軟らかい未〜半固結土はほ とんど崩れていない ${ }^{6)}$ 。

タイプ 6 はマサの剥離・転倒である。このタイプは節 理面の残っている化学的風化があまり進んでいないマサ で発生したもので, 化学的風化による粘土化で節理面が 失われたマサでは発生事例がなかった。これは豪雨時に マサで多発する斜面崩壊とは大きく異なる現象である。

タイプ 7 は弱風化岩とマサとが混在分布する道路沿い の切土法面で発生している (写真-1)。そこでの混在



写真一 1 弱風化岩 $\left(C_{M}\right.$ 級岩盤) 中の節理に囲まれた岩塊 の跳びだし（2000年鳥取県西部地震時に発生した タイプ 7 の落石)

( $D_{H}$ 級岩盤のマサは一切崩れていない。)

Photo 1 Jump of jointed blocks from weak-disintegrated granite ( $C_{M}$ class of rock mass classification) (rock fall of type 7 caused by the 2000 TottoriKen Seibu Earthquake)

(Rock mass of $D_{H}$ class does not collapse.)

分布は断層運動による破壊に起因したものではなく, 後 述するようにラミネーションシーティングの有無に起因 したものである。岩盤の緩みや化学的風化はラミネー ションシーティングの発達した部分で進行し, その部分 は現在マサになっている。法面掘削後の浸食はマサで一 方的に進行するために, 弱風化岩は浸食を免れて凸型微 地形を形成している。落石は弱風化岩中の節理に囲まれ た岩塊の横跳びで生じているが, マサの部分はほとんど 崩れていない。岩塊の跳びだしやすさは弱風化岩がつく る凸型微地形の形態と節理の分布に規制されており, 弱 風化岩の端部から崩落しているものが多い。

このようにタイプ 7 の落石・崩落は弱風化岩とマサと が不規則に分布する部分が掘削によって急勾配の切土斜 面法面に現れたことと, 掘削後の差別浸食による凸型微 地形形成が素因となって発生している。そこで，このよ うな落石・崩落をタイプ 7 として新たに分類した。

\section{3. 花崗岩地域の落石・崩落発生の地質条件}

比較的新鮮で割れ目の少なくて大きな岩塊の集まった 花崗岩は崩れやすくて, 風化・劣化の進んだマサや岩塊 は新鮮であっても細かく割れている花崗岩は崩れにくい 一これが地震時斜面変動の特徴である。地震時にマサが 破壊されにくい原因はいくつか考えられる。マサは新鮮 な岩盤に比べて空隙が多く, 見かけの質量が小さいため に，大きな慣性力が得られない22。また，マサは鉙物粒 
子間の摩擦や空隙部 (空気・水) を振動するときに生じ る抵抗で振動エネルギーが減衰するほか, 塑性変形に よっても破局的な破壊が免れると考えられる

落石・崩落の発生頻度をタイプ別にみると，兵庫県南 部地震や鳥取県西部地震, 芸予地震のいずれの地震でも, 尾根上に分布する花崗岩巨碟の転倒が落石となった夕イ プ 1 が多発している。尾根部での花崗岩巨礫の形成こそ が花崗岩地域での落石発生頻度を高めている原因である。 ではそれはどのようにして形成されたものであろうか。

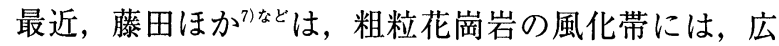
域に数mmオーダーの間隔の微細な割れ目群がほぼ水平 に発達していて，その微細な割れ目群発達領域である風 化帯から, その深部の新鮮岩への移行は急激であること を明らかにしている。このような微細な割れ目群は風化 進行以前の新鮮岩に発生し, 化学的風化を伴うマサ化は 微細な割れ目群に沿って浸透した地下水と岩との反応に よって進行したものであると考えている。そしてマサ中 の未風化核岩の形成は微細な割れ目群形成と同時期であ ると考えている。本論文では，このような微細な割れ目 群をラミネーションシーティングと呼ぶ。

花崗岩巨碟の多くは深部の新鮮岩の分布域と浅所部の マサの分布域との境界付近に存在していた未風化核岩に 由来するものである。浸食小起伏面をつくっていたが風 化帯が浸食される過程でこういった未風化核岩が巨碟と して尾根部に残留する状況がつくられる。マサの部分が 浸食で失われて「裸」になった未風化核岩，すなわち花 崗岩巨碟は不安定な状態にあることが多いので，地震時 には容易に転倒・落下し，タイプ 1 の落石の発生頻度が 高くなったと考えられる。

ところで, タイプ 2 の落石・崩落は兵庫県南部地震で は多発しているが，鳥取県西部地震と芸予地震ではほと んど発生していない。一方, 鳥取県西部地震と芸予地震 では，兵庫県南部地震ではあまり見られなかった夕イプ 7 の落石・崩落が多発している。それらの理由はつぎの ように考えられる。

タイプ 2 とタイプ 7 とでは，どちらの落石・崩落の方 が発生しやすいであろうか。新鮮岩と弱風化岩とでは破 壊面となった節理面の性状に差異が認められる。すなわ ち, タイプ 2 の発生源となった新鮮岩内の節理面は密着 性が高く破壊しにくい。それに対して，タイプ７の発生 源となった弱風化岩内の節理面は密着性が低いだけでな く，すでに開口していることもある。さらに，タイプ 7 の場合は，振動エネルギーの減衰の度合いがマサと弱風 化岩で大きく異なるために，両者間での応答周期の違い による剥離効果が働いた可能性や，後述するような地形 効果による地震動の増幅が起こった可能性もある。以上 のようなことから, 地震動が小さい場合には, タイプ 7 の落石・崩落は発生しても, タイプ 2 の落石・崩落は発 生しないという状況も生まれると考えられる。

建物や土木構造物, 道路などの被害程度から地震動の
大きさを比較してみると，明らかに破壞的な地震動は兵 庫県南部地震の方が鳥取県西部地震や芸予地震よりもは るかに大きい。ゆえに，兵庫県南部地震で多発した夕イ プ 2 の落石・崩落が鳥取県西部地震や芸予地震ではほと んど見られなかったのである。しかし, タイプ 7 の落石 . 崩落が六甲山地で発生しなかった理由を地震動の大きさ の違いで説明することはできない。もっともらしい理由 は六甲山地では夕イプ 7 の落石・崩落を発生させる道路 法面が存在しないということにあると思われる。何度と なく豪雨災害を被った六甲山地の山岳道路は，主要観光 道路ということもあって，ほとんどのところで何らかの 対策工が施されていて，弱風化岩とマサとが混在した花 崗岩が露出しているところがないのである。また，六甲 山頂部を走る道路沿いには切土法面に露岩しているとこ ろもあるが，そこではマサが露岩しているために地震時 には崩壊していない。

鳥取県西部地震における根雨花崗岩でも，芸予地震に おける呉花崗岩でも, ラミネーションシーティングの発 達している部分がマサになり，発達していない部分が風 化されずに残る傾向がある ${ }^{34)}$ 。芸予地震時に落石・崩落 が集中した呉市北西方の二級峡右岸山腹の道路法面では, 石英をほとんど含まない閃長岩〜閃長岩質花崗岩や，細 粒のアプライト〜アプライト質花崗岩，あるいはそれら の岩石を部分的に含む岩塊の落石・崩落が多く見られた。 一般に花崗岩類の中でも石英にそしい岩型や細粒岩はラ ミネーションシーティングが発達しない亲。呉市北西で も, 閃長岩〜閃長岩質花崗岩やアプライト〜アプライト 質花崗岩にはラミネーションシーティングが発達せず, その結果風化・浸食が進まないために，そこが凸型微地 形をなしていて，地震時に落石・崩落となっだ)。

兵庫県南部地震, 鳥取県西部地震, 芸予地震のいずれ の地震においても, 花崗岩地域では落石・崩落が多発し たのに，それと隣接して分布している中・古生界の堆積 岩類や中生代の火山砕屑岩類，第四紀の火山岩などでは 落石・崩落が多発しなかったのはなぜであろうか。それ は，上記の花崗岩以外の地質体では，それらの風化特性 に起因して，タイプ1の源となる巨碟が不安定な状態で 尾根上に分布することが少なく，またタイプ 7 の素因で ある強度差の大きい弱風化岩と強風化岩とが切土法面に 混在して出現することも少なかったからである。

では, 兵庫県南部地震では, 新鮮な花崗岩の露頭崖で タイプ 2 の落石・崩落が多発したにもかかわらず，花崗 岩の壁岩やルーフペンダントとなっている中・古生界の 堆積岩類起源のホルンフェルスや中生代の火山砕屑岩類 からなる新鮮岩の露頭崖では, 落石・崩落がほとんど発 生しなかったのはなぜであろうか。それは節理系の発達 の違いに原因がある。すなわち，花崗岩には平滑な破断 面をもつ方状節理が全域に発達していて，転倒を起こし やすい直方体形状の岩塊が形成されやすいのに対して, 他の地質体では節理の連続性，規則性，破断面の平滑性 
がそしく，露頭崖から容易に抜け出す岩塊が形成されに くいからである。

ただし，地震時に基盤の地質に関わりなく起こる表層 崩壊は区別しておく必要がある。芝生や笹など，成長し た根が絡み合って「マット」を形成しているところでは， 地震時には地表部のマットがその直下の地質体から剥離 してずり落ちる。たとえば，1993年北海道南西沖地震や 1994年北海道東方沖地震では, 笹や芝生のマットの剥離 が多発し，マットの末端部がたたんだ布団のように過褶

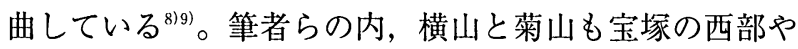
淡路島北淡町で兵庫県南部地震時に芝生からなるマット の剥離による表層崩壊を観察している。またテフラも， 1949年今市地震で見られるように，基盤の地質体と関わ りなく, 表層崩壊を起こしやすいようである ${ }^{100}$ 。したがっ て, 花崗岩地域であっても, 花崗岩の地質特性とは無関 係の表層崩壊が発生することもあるので注意をしなけれ ばならない。

\section{4. 花崗岩地域の落石・崩落発生の地形条件}

兵庫県南部地震で発生した落石・崩落の地形条件につ いては，多くの研究者が共通した認識をもっていること が明らかになっている2。公表されたものをまとめると 地形条件として，(1)尾根部，(2)遷急線付近，(3)露頭崖, (4)急斜面，(5)凸型斜面といった地形因子が挙げられてい る。これらの地形条件は花崗岩以外の地質体でも認めら

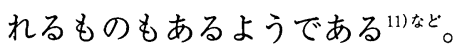

六甲山地で露頭崖が出現する頻度が高いのは谷底付近 の両側斜面であるので, 露頭崖の出現率だけを見ると, 落石・崩落の発生頻度は谷底付近で最も高くなるはずで ある。しかし，現実はそれとは違って，尾根の遷急線付 近の露頭崖からタイプ 2 の落石・崩落が多発している ${ }^{122}$ 。 またタイプ 1 の落石も尾根上に分布していた花崗岩巨砂 の転倒・移動が引き金になっているが，谷底に分布して いた花崗岩巨磁はほとんど転倒・移動を起こしていない。 鳥取県西部地震や芸予地震で多発したタイプ 7 の落 石・崩壊でも, その発生部位というのは法面の上部で, そこは法面上方の自然斜面と法面がつくる遷急線直下に あたっている（写真－1）。さらにタイプ 7 の落石・崩 落が発生した弱風化岩は凸型微地形をなしている。地震 時応答解析のシミュレーションによれば，地形の凸部で 地震動が増幅することが明らかになっている(21)13)。落石・ 崩落現場の地形とシミュレーション結果とを結びつけて 考えると，尾根肩の遷急線付近や，凸型横断形を呈する 斜面, 周辺に比して盛り上がっている凸型微地形など 様々なスケールの凸型地形部で, 地震動の増幅が引き起 こされ，それが落石・崩落の原因になっているものと推 定される。

\section{5. 落石の落下方向の予測}

落石災害の防止あるいは軽減を考えるとき，地震時落
石・崩落の落下方向が予測できるかどうかということは 重要問題である。その予測ができるならば，尾根の方向 や露頭崖の向きが地震動の摇れの方向との関係で落石 · 崩落が発生しやすい方向を向いているかどうか, 花南岩 巨碟はどの方向に落下する可能性が高いかといったこと を考慮にいれた防災対策が可能になるからである。

兵庫県南部地震の際に, 淡路島北部から西宮市にかけ ての地域では少なくとも地下深部の断層は破壊を起こし た。この地域では, 墓石・灯籠の卓越転倒方位から, 兵 庫県南部地震による卓越水平加速度方位が既存の活断層 に直交する傾向があることが分かっている5)。こういっ た水平地震動の方位に地表変状も方向規制を受けている。 たとえば，(1)木造家屋の倒壊方位，(2)六甲アイランド周 辺のケーソン式岸壁の傾動や水平移動の方位，(3)盛土中 の開口クラックの方向である5)。阪神高速道路（神戸線） の高架の倒壞も同様の方向規制を受けた結果と思われる。 そして, 六甲山地における花崗岩巨磉の転倒 (タイプ 1) の方位のほか, 露頭崖からの崩落 (タイプ 2 ) の方位も 水平地震動の方向規制を受けている（図-2）。

鳥取県西部地震や芸予地震でも, タイプ 1 とタイプ 7 の落石・崩落の方位が一定の方向に向いている ${ }^{3 / 4)}$ もち ろん, 露頭崖で発生したタイプ 2 や道路法面で発生した タイプ 7 は当然斜面の向きの影響を受けるし，節理面の 方向の影響も受けるはずである。にもかかわらず,落石・ 崩落の卓越方位がある範囲に集中するのは水平地震動に よる方向規制を受けているためと考えられる。

鳥取県西部地震では, 菅沢ダム（日南湖）の周囲を取 り巻く道路沿いで落石の落下方位を測定したデータがあ る（図-3）。測定を実施した道路の全体的な方向はN

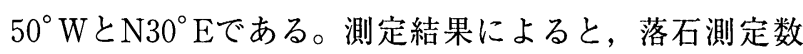
26箇所の内の $80 \%$ 以上がSW $10^{\circ} \sim 70^{\circ}$ の落下方位を向い ている。余震の分布から推定された震源断層の方向はN $28^{\circ} \mathrm{W}$ あるるので, 多くの落石はこの震源断層の法線方 向を中心とする $45^{\circ}$ の範囲に入っていることになる。

兵庫県南部地震や鳥取県西部地震のように, 水平地震 動の方位が破壊を起こした活断層に直交する方向を向く ということが一般にいえるなら，直下型地震で発生した 落石・崩落については, 活断層の方向から落下方位を予 測することが可能である。

\section{6. 落石の到達距離の予測}

誘因に関わらず，落石の到達距離は落下高さと移動域 の斜面の性状㧍よび停止域の傾斜に制約される。鈴木 ${ }^{14}$ は急傾斜地の自由面の崖頂から崖錐末端までの比高を落 下高さとし, 崖頂から崖錐末端までの水平距離を落石の 到達距離として, 両者の関係を調査している。それによ ると, 落下高さが高くなるほど, 到達距離は長くなる傾 向があり, 最大級の崖錐斜面では到達距離は落下高さの 5 倍にも及ぶ。これは落石が自由落下後に崖錐斜面を転 がりながら移動したためで, 古い崖錐ほど到達距離は長 


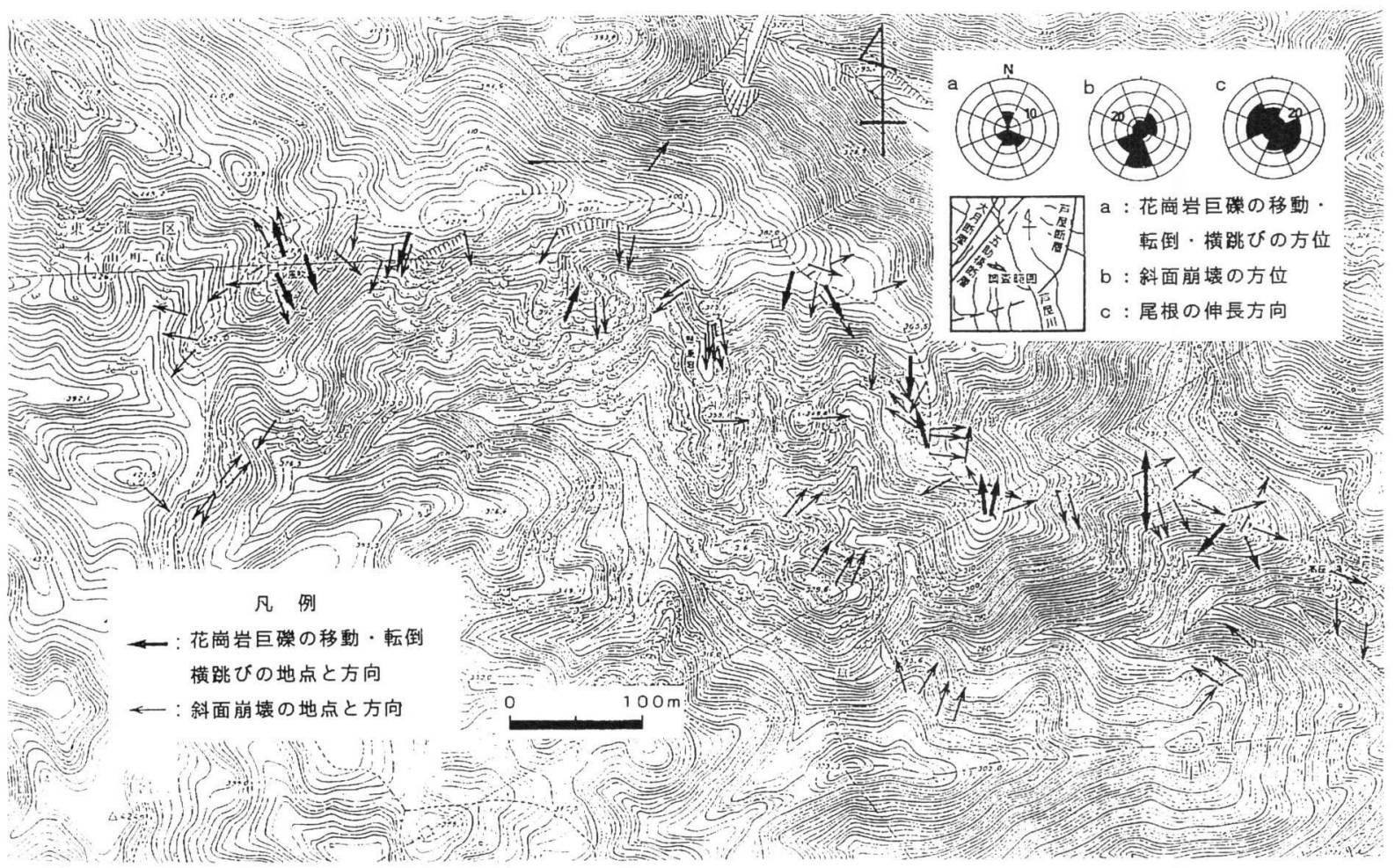

図－２１995年兵庫県南部地震による花崗岩巨礫の転倒・移動の方位と斜面崩壊の方位（芦屋のロックガーデン）

Fig. 2 Orientation of migration, topple and jump of granite boulders, and slope failures (Asia Rock Garden) ${ }^{7}$

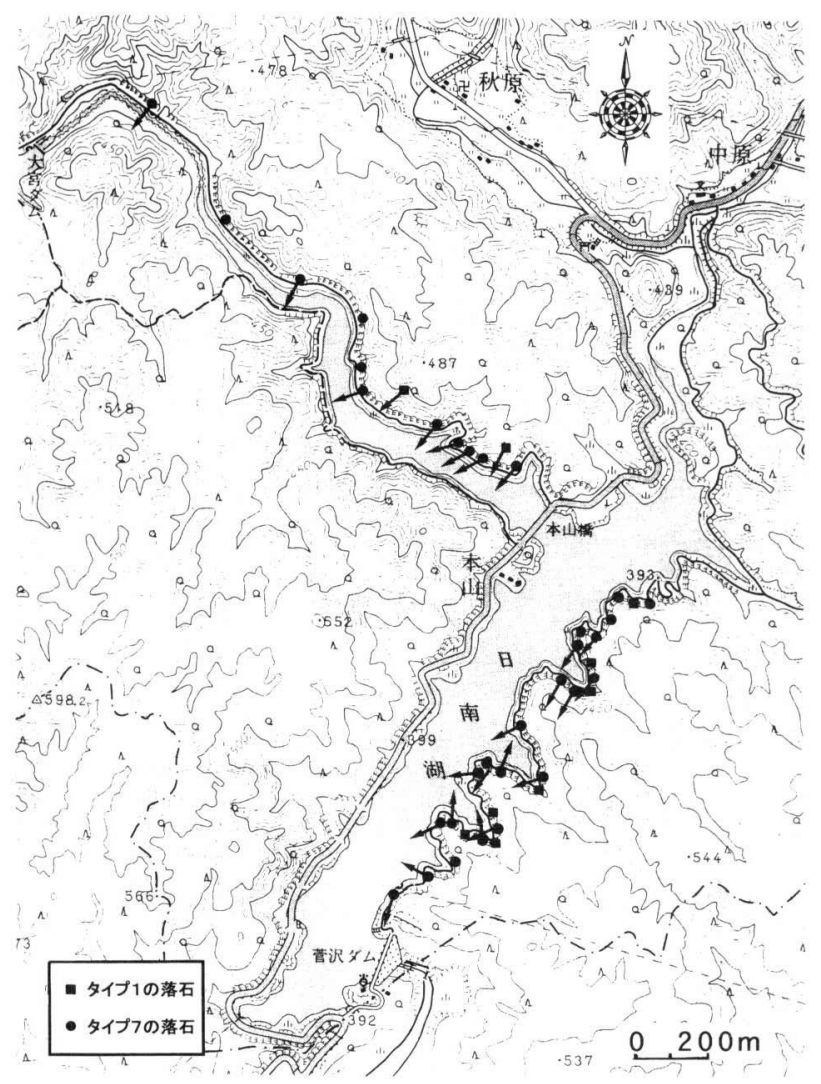

図－３2000年鳥取県西部地震による落石の落下方向（菅沢 ダム日南湖）

Fig. 3 Falling direction of rock falls caused by the2000 Tottori-Ken Seibu Earthquake (Nichinan Lake of Sugesawa Dam)
くなる。

鳥取県西部地震時に菅沢ダム沿いでは，長径数 $10 \mathrm{~cm}$ 程度の角張った岩塊が高さ $10 \mathrm{~m}$ 以下の道路法面から多数 落下している。これはタイプ 7 の落石・崩落である。大 部分の岩塊は崖面を転がり落ちることなく，直接路上に 落下している。

このような落石について落石の落下高さと到達距離の 関係を調查したデータがある。それによると，岩塊は落 下後も路面をほとんど転がることなく停止している。そ こで法尻から落石発生位置までの高さを落下高さとし, 落石発生位置から停止位置までの水平距離を到達距離と して，両者の関係を見ると，到達距離は落下高さにほぼ 等しいという結果が得られた（図－4）。1987年千葉県 東方沖地震による上総丘陵の小規模な斜面崩壊の計測結 果でも, 到達距離は落下高さにほぼ等しいという結果が 得られている ${ }^{15)}$ 。菅沢ダム周辺には震度の計測データは ないが, 落石・崩落や道路構造物の破損状況を兵庫県南 部地震の場合に当てはめて推定すると, 調查地の平均的 な震度は 5 強〜 6 弱程度であろう。もし水平地震動がそ れより大きくなれば，落下高さが同じでも，到達距離は この結果よりも長くなるであろう。

尾根上の花崗岩巨碩の崩落（タイプ1）や露頭崖から の崩落（タイプ 2 ）も，落下直後に停止すれば，その距 離は夕イプ 7 の落石の到達距離と変わらないものと予想 される。しかし，通常，夕イプ 1 や夕イプ 2 の落石は, 落下後，山腹斜面を転がることになり，樹木などの障害 


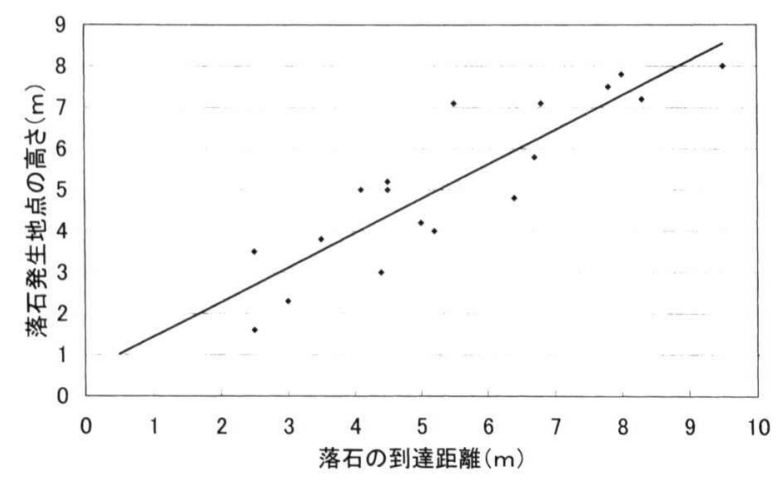

図ー4 2000年鳥取県西部地震によって道路切土法面から発 生したタイプ7の落石の落下高さと到達距離（自由 落下距離）の関係（菅沢ダム日南湖）

Fig. 4 Relation between distance of free-falling and height of falling position on rock falls from roadcuts, caused by the 2000 Tottori-Ken Seibu Earthquake (Nichinan Lake of Sugesawa Dam)

物にトラップされなければ，長距離を移動して山麓の低 地まで到達する。山腹を走る道路くらいの幅なら，たと え平坦は路面に落下したとしても, 路面上で停止するこ となく, 路面上をジャンプし, さらに写真 -2 のように コンクリート製防護壁を突き破って山腹斜面を落下して いる。

他方, 花崗岩巨碟を取り巻く風化殼の剥離 (タイプ 7 ) やタイプ 6 のようなマサの崩落ではほとんど横跳びする ことなくその場に落下している。

地震時落石の落下経路が詳しく調べられた事例はほと んどないように思われる。ここでは, 鳥取県西部地震時 に発生したタイプ1の落石の落下経路と被災状況をそれ ぞれ平面図 (図 - 5 ) と断面図 (図 - 6 ) に示す。この 事例では, 長径4. $3 \mathrm{~m}$ の花崗岩巨碟が標高 $465 \mathrm{~m}$ の発生地 点から自然斜面に沿って $127 \mathrm{~m}$ の距離を落下して, 最終 的には標高 $400 \mathrm{~m}$ のダム湖畔の砂堆上で停止した。落下 経路は, 落石の衝突の証拠である樹木の擦痕・折木・倒 木や, 落石の着地の証拠であるインパクトクレーターに よって推定された。樹木の高い位置に刻まれた擦痕は落 石のジャンプを示唆している (写真-3)。インパクト クレーター内では落石はしばしばすべりを起こし, 前面 に土を押し出していることから，多くのインパクトク レーターはジャンプした落石の着地を示しているものと 推定される。落下経路全体を通してみると, 落石は遷急 線のところでジャンプを繰り返しながら落下したものと 推定される。

この事例の落石は, 発生直後の自由落下距離が約 $5 \mathrm{~m}$ に過ぎない。しかも落下過程では, 多くの樹木への衝突 によって運動エネルギーが失われている。こういった状 況にも関わらず，長距離移動し得たのは，落石が水平地 震動による慣性力で跳びだしたこと, 斜面が 35 度の平均 勾配をもっていたこと,さらにもうひとつ重要なことと して, 比較的樹木の少ない谷に沿って落下したことを挙

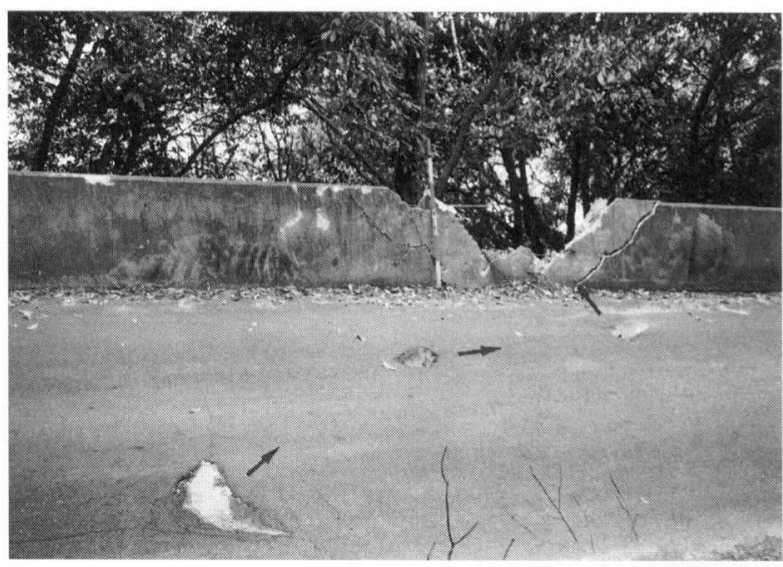

写真一 22001 年芸予地震時に発生した花崗岩巨磁の衝突 （タイプ 1 の落石）による道路の破損

(直方体の花崗岩岩塊 $(120 \times 80 \times 50 \mathrm{~cm})$ が道路に落下し, 路面上 をジャンプしながら移動した後，ついには路肩のコンクリート製 防護壁を突き破ってさらに斜面を $80 \mathrm{~m}$ 落下した。花崗岩破片が路 上のインパクトクレーターにめり込み, 環状と放射状のクラック がクレータの周りに発生している。)

Photo 2 Damage of road due to clash of granite boulder (rock fall of type 1) caused by the 2001 Geiyo Earthquake

(Rectangular parallelepiped block of granite $(120 \times 80 \times 50 \mathrm{~cm})$ fell down and migrated with jumping on road, finally crashed through concrete safety wall of road shoulder and fell down on slope of distance of 80 meters. The fragments of granite sank into asphalt roadsurface in impact crater, and ring and radial cracks run around the crater.)

げることができる。地震時落石の多くは, 溝状山地のよ うな小規模な谷でも，一旦谷に入ってしまえばそれに 沿って落下し, 山麓線を越えて平地に出てからも移動し ている。しかし, 谷でない斜面を落下した落石は樹木に トラップされ, 山麓線を越える前に停止しているものが 多い。このように谷の存在が落下経路や落下距離を規制 することから, 発生場所と 0 次谷や 1 次谷との位置関係 から保全対象物に対する落石被害の危険性をおおよそ予 測することができる。

\section{7. 地震時落石・崩落の発生場所の予測方法}

これまでに述べてきたことから明らかなように，花崗 岩地域において地震時落石・崩落が多発する原因は, 花 崗岩の風化带構造とそれがつくる特有の地形と深く関係 している。そうであるならば，風化帯構造と地形から， 落石・崩壊の発生場所を予測することが可能である。

落石災害の防止と軽減を目的とするならば，予測対象 とすべき落石・崩落は発生頻度の高い夕イプ1, タイプ2, タイプ 7 とすることが現実的である。これらの落石・崩 落がどのような地形・地質条件のところで発生するかに ついては上述したようによく分かっているので, 調查地 域の全域を隈なく踏査して, 個々の花崗岩巨砂や露頭崖 を診断すれば, 精度の高い予測図は完成する。しかし, それでは調査効率 (経済性) がよくない。そこで，まず は上記 3 タイプの落石・崩落が発生する危険性の高い地 


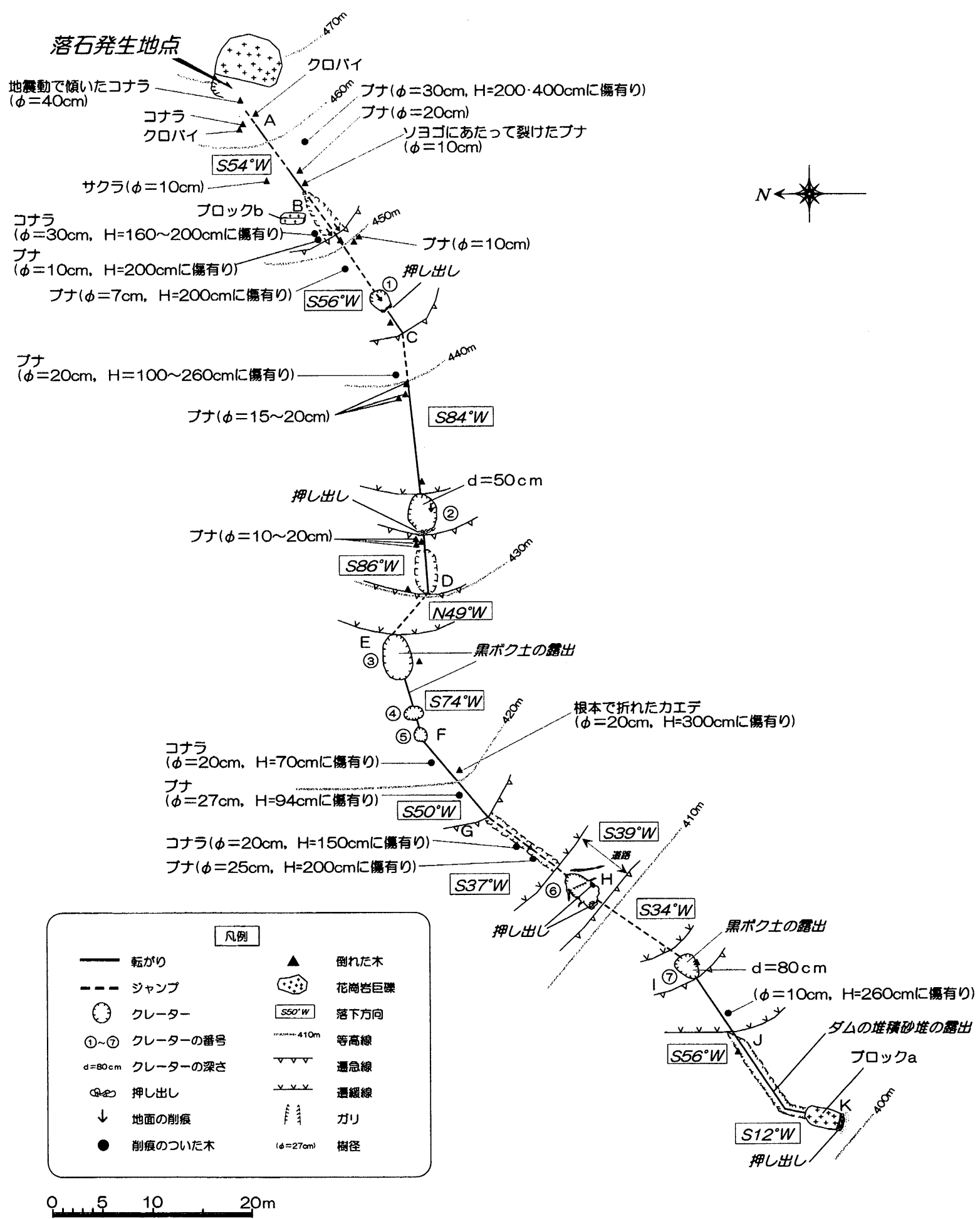

図一 52000 年鳥取県西部地震時に発生した花崗岩巨礫の落石経路と落石衝突による被害 ${ }^{3)}$ (図一 6 に対応する)

Fig. 5 Falling route of granite boulder caused by the 2000 Tottori-Ken Seibu Earthquake and damage due to clash of the boulder 3$)^{3)}$ (See Fig. 6)

域を地質図や地形図，空中写真等を使って机上で絞り込 み，つぎに絞り込まれた地域において現地踏査を行って 個々の花崗岩巨鿬や露頭崖を診断するという方法を提案 する。

(1) ステップ 1 ：地質図の活用

現在の日本では，旧地質調査所発行の地質図をはじめ
として，多くの論文から花崗岩の分布や岩相を知ること ができる。通常, 節理間隔が広く, 風化・浸食によって 巨碟が生成されやすい岩相は粗粒で岩石学的にはアダメ 口岩や花崗閃緑岩に分類される粗粒花崗岩である。発生 場所予測ではこの粗粒花崗岩が対象になる。 

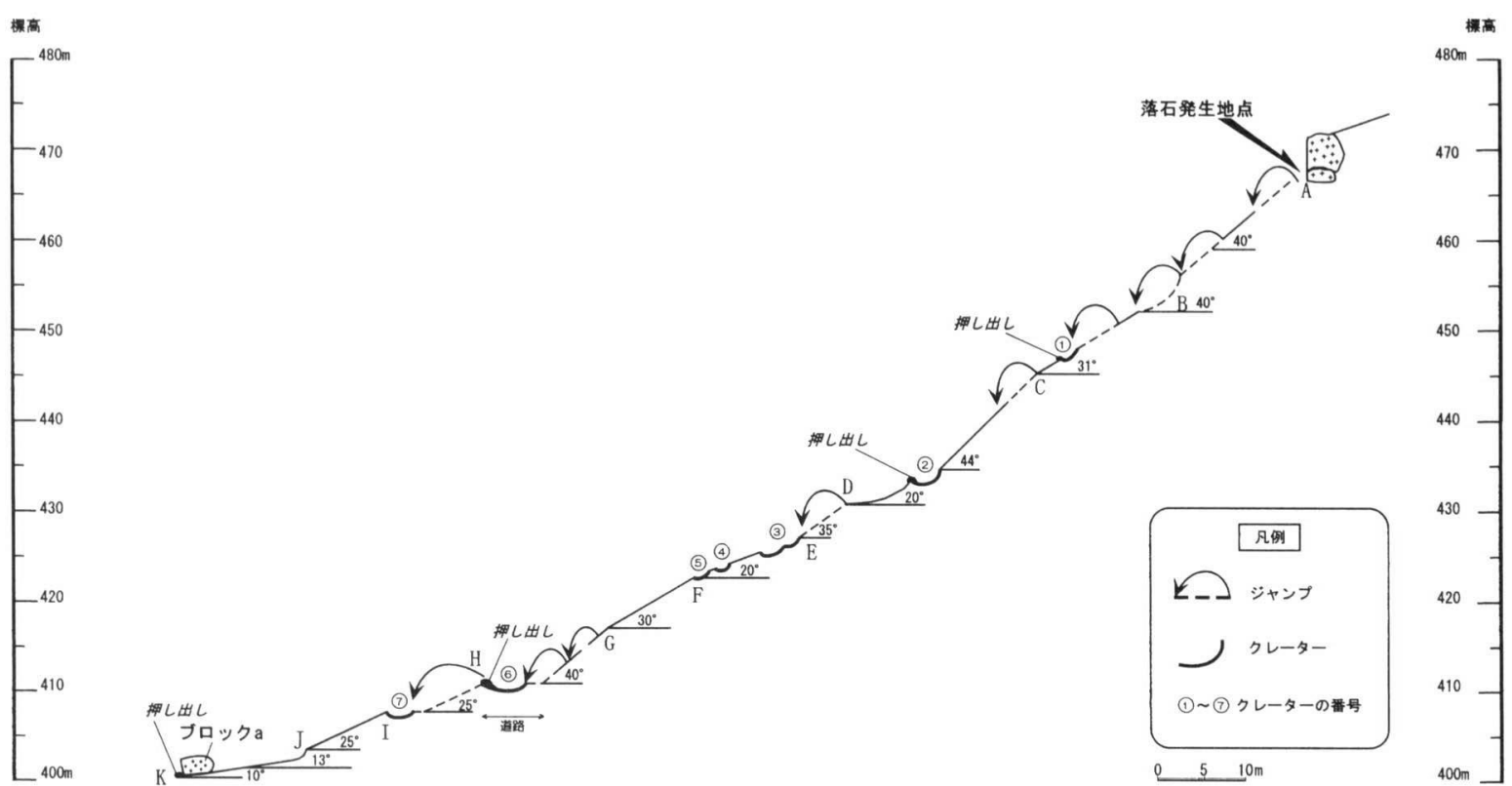

図－６2000年鳥取県西部地震時に発生した花崗岩巨礫の落石挙動 ${ }^{3}$ (図一 5 に対応する)

Fig. 6 Falling behavior of granite boulder caused by the 2000 Tottoria-Ken Seibu Earthquake ${ }^{3)}$ (See Fig. 5)

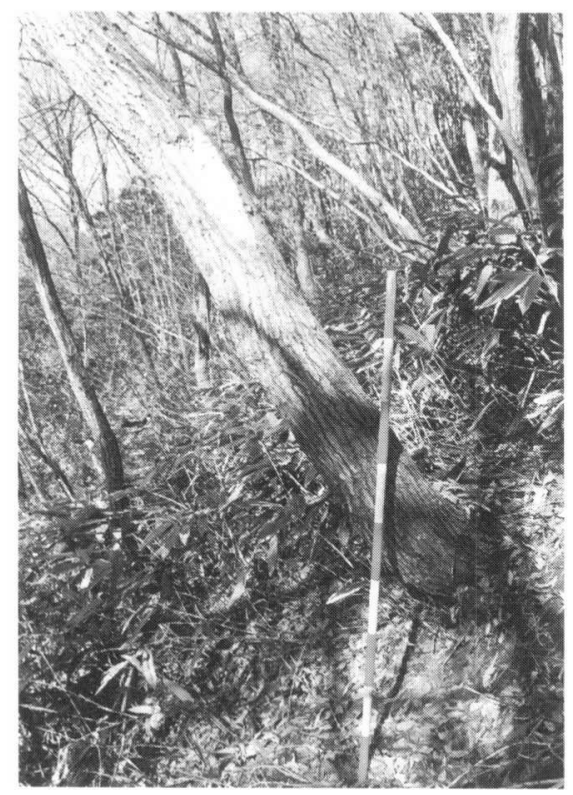

写真一 3 花崗岩巨礫の衝突によって擦痕の付いた樹木 (2000年鳥取県西部地震)

Photo 3 Trunk of a tree scratched by clash of granite boulder (the 2000 Tottori-Ken Seibu Earthquake)

\section{(2) ステップ2 : 風化マップの活用}

花崗岩の風化マップ（風化帯区分図）があれば，マサ と新鮮岩の分布が分かるので, 地形図と組み合わせて, 新鮮岩が露出している尾根や露頭崖を抽出することがで きる。さらに花崗岩巨䃇の分布が示されていれば，精度 よく危険地域を絞り达むことができる。こうして室内で の絞り込み作業の大半は終了する。しかし, 残念なこと にほとんどの地域で花崗岩の風化マップは作成されてい
ないのが現状である。

(3) ステップ 3 : 空中写真判読

そこで, 空中写真判読から, 花崗岩巨䃇や露頭崖の分 布, 道路法面の露岩状況を把握することを試みる。ただ し, その成果は空中写真の縮尺や撮影時期, 植生状況に よって大きく左右されるので注意が必要である。風化 マップが存在する場合も, 詳細を確認する上で空中写真 判読は有効である。

\section{(4) ステップ 4 ：地形図の活用}

地形図から，崖や露岩，道路，法面の位置を読みとる。 地形図の縮尺によっては法面形状や勾配を読みとること ができる。また崖記号が記入されていなくても，等高線 が密になっている領域には露頭崖が分布している可能性 がある。最後に明瞭な遷急線に囲まれた尾根を抽出し， とくに抽出した尾根が凸型やせ尾根の場合は最重要踏査 地域としてマークしておく。

(5) 現地踏查対象地域の絞り込み

このステップでは, (1)〜(4)の成果を地形図に記述し, その地形四読四結果と合わせて総合的に現地踏査対象地 域を絞り达む。

最も重要な現地踏査地域は花崗岩巨碟が分布すると子 想される尾根である。そういった尾根は凸型やせ尾根を 呈していることが多く, 尾根の肩に明瞭な遷急線が認め られる。そして, 遷急線直下では露頭崖の出現頻度も高 くなる。したがって,「花崗岩巨砂の出現」,「明暸な遷 急線」,「凸型のやせ尾根」,「露頭崖の出現」といった項 日が数多く重なる地域ほど, 夕イプ1と夕イプ 2 の落 石・崩落が発生する危険性が高く, 現地踏查が必要であ る。タイプ 7 の落石・崩落では, 道路法面など切土法面 で, 新鮮岩〜弱風化岩が露出しているか, 弱風化岩とマ 
サが混在分布して露出しているところで現地踏査が必要 である。

(6) ステップ 5 ：現地踏査による診断

現地踏查では, 露頭崖の形状, 花崗岩巨礫の姿勢, 露 頭崖や花崗岩巨碟の位置と遷急線との関係, 風化度, 節 理の方向や分布密度，さらには節理面の緩み状態などが 診断ポイントとなる。落石・崩落の夕イプ毎に，その診 断ポイントを具体的に記すとつぎのようになる。タイプ 1 の落石を発生しやすい花崗岩巨磁は，(1)凸型やせ尾根 上に分布し，(2)巨礫の縦横比や形が転倒を起こしやすい 形状をもっていて，(3)転倒・横跳びすれば容易に落石に なる位置にあるものである。タイプ 2 の落石・崩落を発 生しやすい露頭崖は, (1)遷急線の付近に位置し, (2)新鮮 な岩石からなり，(3)節理に囲まれた岩塊は転倒・横跳び を起こしやすい形状をもち，(4)さらにその節理面が開口 して緩んでいるものである。タイプ 7 の落石・崩落が発 生しやすい道路法面の弱風化岩は, (1)マサと混在分布し, (2)マサとの差別侵食による凸型微地形をなし，(3)法面の 上部に位置し，(4)弱風化岩全体あるいはそのなかの節理 に囲まれた岩塊が剥離・横跳びを起こしやすい形状を もっているものである。

なお，道路を保全対象とした落石・崩落踏査では，道 路法面におけるタイプ 7 の落石・崩落だけはなく, 夕イ プ 1 や夕イプ 2 の落石・崩落も対象となるので，尾根上 までの調査が必要である。また，落下経路についても評 価が必要なので, 花崗岩巨啋や露頭崖と谷筋との関係も 明らかにする必要がある。

\section{8. まとめ}

花崗岩地域では，風化帯構造とそれがつくる特有の地 形に規制されて，地震時には落石・崩落が多発する傾向 がある。多くの落石・崩落は尾根の直上や遷急線の近傍 の露頭崖で発生していて，しかも地震による破壊はマサ や割れ目の多い花崗岩よりも，新鮮で割れ目の少ない花 崗岩の方が著しい。その結果，規模の大きな岩塊が大き な慣性力を得て, 水平地震動の方位とは反対方向に転 倒・横跳びを起こして落石・崩落になる。地震時落石・ 崩落で高い発生頻度を示すタイプは, (1)尾根上の花崗岩 巨砂の転倒・移動から発生する落石，(2)尾根の遷急線近 傍に分布する露頭崖で発生する新鮮岩の落石・崩落，(3) 道路法面の弱風化岩とマサとの混在部で発生する弱風化 岩の落石・崩落である。これらの 3 タイプの落石・崩落 の予測が地震時落石災害の防止と軽減に向けて重要な課
題となる。落石・崩落の発生場所は発生域の地形・地質 条件から絞り込むことが可能である。落石の落下方向は 起震断層に直交する傾向がある。タイプ 7 の落石の自由 落下距離は落下高さに比例して長くなり，ほほ落下高さ に等しい長さをもつ傾向がある。落石挙動は個々の状況 に依存し，一義的に現象を予測することは難しい。こう いった現象については帰納法的に認められる「傾向関係」 に基づいて予測方法の向上を図ることが現実的である。

\section{引用文献}

1）沖村孝（1995）：兵庫県南部地震にともなう斜面崩壊の特性, 兵庫県南部地震等にともなう地すべり - 斜面崩壊研究報告書, 地すべり学会, pp. 1- 16 .

2 ）横山俊治・菊山浩喜（1997）：1995年兵庫県南部地震時に発生 した六甲花崗岩地域の斜面崩壊の運動様式と機構, 地すべり, Vol. 34, No. 3, pp. $17-24$.

3 ）水口真一・藤田勝代 · 嘉茂美佐子 ·加藤弘徳 - 中野浩 - 大谷 竹志郎・横山俊治・横田修一郎 (2001)：2000年鳥取県西部地 震による落石特性, 島根大学鳥取県西部地震災害調查報告書, 島根大学鳥取県西部地震災害調查団, pp. 51-60.

4 ）嘉茂美佐子・水口真一・横山俊治・瀬尾孝文（2001）:2001年 芸予地震による呉市周辺の花崗岩地域の落石, 第40回日本地 すべり学会研究発表会地すべり2001講演集, pp. 513-516.

5 ）横山俊治・菊山浩喜（1995）：墓石・灯籠の転倒方向からみた 1995年兵庫県南部地震の水平地震動の方位と地表变状の方向 規制，地質学論集，No. 51,pp. 78-88.

6 ）横山俊治・菊山浩喜・田中英幸・海谷叔伸（1997）：1995年兵 庫県南部地震による盛土の地表変状の原因, 構造地質, No. 42 , pp. $51-61$.

7 ）藤田勝代・菊山浩喜・田中英幸・横山俊治（2001）：小豆島の 花崗岩に見られるラミネーション・シーティングの発生と成 長に起因した岩盤の緩みと斜面変動，第40回日本地すべり学 会研究発表会地すべり 2001講演集, pp. 591-594.

8 ）山岸宏光・雨宮和夫・黑沢邦彦 (1994）：奥尻島および島牧・ 北桧山海岸の斜面災害, 地下資源調查所調查研究報告, No. 24 , pp. 5-29.

9 ) 田近淳 ·伊藤陽司 - 石丸聡 - 広田知保 (1995)：根室 - 釧路地 方の斜面変動，地下資源調查所研究報告，No. 25, pp. 81-94.

10）井口隆（1995）：谷埋め盛土地盤における地震時地すべりの 事例と若干の考察, 兵庫県南部地震等に伴う地すべり・斜面 崩壊研究報告, 地すべり学会, pp. 101-119.

11）奥園誠之・羽根田汎美・岩竹喜久磨（1980）：地震による斜面 崩填の実態，土と基礎，Vol.28, No. 8, pp. 45-51.

12）落合博貴・北原曜・三村利昭・阿部和時（1995）：地震による 山腹斜面崩壊と地震応答解析, 兵庫県南部地震等にともなう 地すべり・斜面崩壊研究報告書, 地すべり学会, pp. 119-132.

13）仲野公章（1984）：地震，高橋博 - 大八木規夫 - 大滝俊夫 - 安 江朝光編纂：斜面災害の予知と防災，白亜書房, pp. 259-268.

14）鈴木隆介（2000）：落石，建設技術者のための地形図読図入門 第 3 巻 段丘·丘陵 - 山地, 古今書院, 東京, pp. 793-795.

15）釜井俊孝・野呂春文（1988）：1987年千葉県東方沖地震による 上総丘陵の斜面崩壊，応用地質，Vol. 29, pp. 285-294.

（原稿受付2001年11月20日，原稿受理2002年 4 月22日） 